\title{
The Influence of Web Based Cooperative Information System to Improve the Quality of Member Service in Universitas Muhammadiyah Sukabumi
}

\author{
Sakti Alamsyah ${ }^{1}$, Eris Darsawati ${ }^{2}$, Darmo H Suwiryo ${ }^{3}$ \\ ${ }^{1}$ Faculty of Economics, Universitas Muhammadiyah Sukabumi, Indonesia \\ Correspondence: Eris Darsawati, Faculty of Economics, Universitas Muhammadiyah Sukabumi, Indonesia.
}

Received: October 24, 2018

Accepted: November 13, 2018

Available online: November 21, 2018

doi:10.11114/ijsss.v6i12.3713

URL: https://doi.org/10.11114/ijsss.v6i12.3713

\begin{abstract}
The role of cooperative is still very important in Indonesia and technology development compels cooperative to change in management especially in presenting data that is more accurate, complete, fast, and transparent. University Cooperative keeps on innovating in giving service to members. This paper tries to present university cooperative information system that aims at increasing service quality by providing university cooperative information system website. Therefore, cooperative member is able to observe cooperative development online. Research method applies qualitative descriptive analysis. Population is member cooperative finance report. Sample is taken by purposive sampling. Research instrument applies questioner to management to know how the influence of cooperative information system toward management achievement and to cooperative member to know member response toward cooperative information system program. Data collection is done by interview to cooperative management and finance data processing is done by using university cooperative information system application. The result of service quality toward member is fast in providing more accurate data with the availability of cooperative information system so that data which is wanted can be obtained faster, accurate, and can decrease mistake in writing data process and decrease mistake in presenting finance report.
\end{abstract}

Keywords: cooperative, information system, website

\section{Introduction}

In globalization era and technology development, role of cooperative is expected to be able to become a member-owned organization all at once it can be a better alternative compares to other organization. Indonesian cooperative is still important even though it must deal with globalization era which are more competitors from abroad. The role of cooperative as an economy organization has contribution in Indonesian economy. In its development, cooperative should have role in helping government to make social and economy justice yet in reality it does not still play a role maximally.

Cooperative of Universitas Muhammadiyah Sukabumi as an economy facility has a great role toward member and feels to challenge to raise service toward cooperative member. It is caused that the management has main activity as a lecturer and staff in Universitas Muhammadiyah Sukabumi.

The research aims to combine technology development recently that cooperative change management in presenting data that is more accurate, complete, fast, exact, and transparent so that cooperative development as business organization enables to have good competition with other business organization suitable with etiquette and business norm in Indonesia. Information technology is an opportunity for cooperative to show how far cooperative potency in order to keep survive in competition that has effectiveness, efficiency, and entrepreneur professionalism to what can do to develop cooperative in empower society in economic potency. The use of information technology applies university cooperative information system programe.

University cooperative information system programe is an information system which is applied to university cooperative as innovation in increasing service to member through providing website so far as member enables to use information technology to observe and check cooperative development by online, easy to access between member, management, and supervisor therefore it results fast data, an accuracy data and can decrease mistake in writing data process and decrease mistake in presenting finance report that is expected by all parties so far as service quality toward member is more maximal. 


\section{Literature Review}

The development of technology and science in information system helps industry in making report process that is suitable with standard. Conceptual model to control computer-based information system, which is very needed by company because company leader or managers need information very much in performing its duty. Such information can be management information, employment, production, finance, and any things that are needed in running company activity to get maximal result (Triani, 2017:1).

In system that consists finance data is known in term accounting information system is an importance factor and is needed by company organization. Accounting information system aims at managing accounting data, which derives from any sources that becomes accounting information that is needed by any kind of users to decrease risk when taking decision for company. Such information user can be from company or out of company such as customer and supplier (Azhar, 2008:8).

Information system is also needed by leader in doing activity as management so that it is needed management accounting system that provides finance information or information, which relates to activity that is not finance especially in doing company operation in certain need in taking decision. Besides it has big benefit for leader in performing his/her duty, management accounting information system is also useful for information user from outsider party such as investor, creditor, government particularly in relating to tax payment (Simamora, 2012:13).

Management information system in general is a system that is integrated to present information to support organization operation function. Siswanto (2005:189) gives a limitation that information system is a group of people and capital sources in an organization that has responsibility to collect and organize data to result useful information for every management hierarchy in planning and controlling organization activity.

Regardless with cooperative is an organization business that consists of people or cooperative organization based on cooperative principle and as economy movement based on family principle (Akyuwen, 2016:77, Sitio and Tamba, 2001). Cooperative grows particularly through credit and consumer so that it can create modern trade chain. Tambunan (2012:311) stated that cooperative can be tough and independence and can develop in creating a strong national economy. Support is done by policy or provides facility and other stimulus. Mechanism and procedure, appropriate, and applied also it guides to appropriteness of effort implementation and effort development with society capability as business element in an economy system based on cooperative.

\section{Research Method}

Research method is a science that studies ways or scientific method in conducting research activity. Such method among other thing: data collection, data analysis, sample decision, and hypothesis test (Sedan, 2015:5). Research method applies qualitative descriptive analysis (Sugiono, 2016).

Variable in research is important position that is as a research object (Indrawan, 2014: 12). There are two variables they are independent variable is cooperative information system meanwhile dependent variable is member service quality. Population is university cooperative member finance report. Sample is taken by purposive sampling (Sumarni and Wahyuni, 2005). Sample is taken by direct observation to all university cooperative members.

Research instrument applies questioner which is given to all managements as member data presentation and data user after getting access university cooperative information system program to know satisfaction level from management in processing data that must be prepared and how this program can increase cooperative service quality. Data collection is done by checking finance data that is made by university cooperative management manually.

The technique is done by direct interview to university cooperative management in order to know difficulty which is faced in making finance report and what hope from program that is expected in presenting data which is completed by note refers to finance and management. Interview is also done to university cooperative member that refer to service which is wanted by member with increasing fast service and accurate.

Furthermore, it is done data processing which is made through the step of manual or system. To get maximal result, it is done data operation combination. When data collection activity ends, collected manual data is processed then finance data is processed by applying computer application program.

\section{Result and Discussion}

Universitas Muhammadiyah Sukabumi as an independence and excellent university is a place of university employee cooperative to give the opportunity to all academics community to develop potency and innovation suitable with strategy and continuity appropriation plan by considering strength and chance that is had by university. The period of university achievement as an excellent university with the target as center of science and technology research and study Islam and Kemuhammadiyah is a chance for cooperative to use technology and information in providing data to 
member that can be accessed in website with university cooperative information system program.

Managing cooperative needs management system that is an activity process consists of planning, organizing, and controlling to reach goal. Cooperative is an organization that must be managed as deserve as other business. In business organization is needed an effective and efficient organization in order to be able to compete with other business organization so that the existence of cooperative can be considered especially in giving a better service.

University cooperative information system which is applied to university cooperative is done as an innovation in increasing service quality toward member by providing website so that member can use information technology to observe and check cooperative development by online. To know the influence of web based cooperative information system to improve the quality of member service is applied simple linear regression analysis aim to measure independent variable coefficient by elasticity score. Independent variable is cooperative information system meanwhile dependent variable is member service quality.

a. Characteristics of Respondents by Gender

The sex of the research respondents can be seen in the following table.

Table 1. Characteristics of Respondents by Gender

\begin{tabular}{clcc}
\hline No & Gender of Respondents & Amount & Percentage (\%) \\
\hline 1. & Man & 33 & 44 \\
2. & Woman & 42 & 56 \\
& Amount & 75 & 100 \\
\hline
\end{tabular}

Source: processed from research result

Based on the table above it can be seen that as many as 33 people or $44 \%$ of respondents were male and as many as 42 people or $56 \%$ of respondents were women.

b. Characteristics of Respondents by Age

Regarding the characteristics of respondents based on age can be seen in the following table.

Table 2. Characteristics of Respondents by Age

\begin{tabular}{clcc}
\hline No & Age of Respondents & Amount & Percentage $(\%)$ \\
1. & $20-30$ years & 22 & 29,3 \\
2. & $30-40$ years & 23 & 30,6 \\
3. & $41-50$ years & 16 & 21,3 \\
4. & $50-60$ years & 14 & 18,7 \\
& Amount & 75 & 100 \\
\hline
\end{tabular}

Source: processed from research result

The table describes the characteristics of respondents based on the youngest age under or 20 years and the oldest age 60 years. Of the 75 respondents consisting of: 22 respondents $(29,3 \%)$ were under or 20 - 30 years old, 23 respondents $(30,6 \%)$ aged $30-40$ years, 16 respondents $(21,3 \%)$ aged $41-50$ years, and as many as 14 respondents $(18,7 \%)$ aged between $50-60$ years.

c. Respondents Based on Education Level

The caharacteristics of respondents based on the level of education can be seen in the following table.

Table 3. Respondents Based on Education Level

\begin{tabular}{clcc}
\hline No & Education Level & Amount & Percentage (\%) \\
\hline 1. & < Senior High School Graduated & 18 & 24 \\
2. & Bachelor Graduated & 30 & 40 \\
3. & Master Graduated & 22 & 29,3 \\
4. & Doctorate Graduated & 5 & 6,7 \\
& Amount & 75 & 100 \\
\hline
\end{tabular}

Source: processed from research result

The table above describes the characteristics of respondents based on education, namely from the number 75 respondents consisting 0f: 18 people (24\%) had a senior high school graduates, with 30 bachelor graduates $(40 \%)$ and 22 master graduates $(29 \%)$. While respondents as many as 5 people $(6,7 \%)$ had doctorate graduates.

d. Respondents Based on Marriage Status

Regarding the characteristics of respondents based on marital status can be seen in the following table. 
Table 4. Respondents Based on Marriage Status

\begin{tabular}{clcc}
\hline No & Marriage Status & Amount & Percentage $(\%)$ \\
\hline 1. & Married & 60 & 29,3 \\
2. & Not Married & 15 & 30,6 \\
& Amount & 75 & 100 \\
\hline
\end{tabular}

Source: processed from research result

The table above describes the characteristics of respondents based on marriage status with 75 respondents consisting of 60 respondents $(18,3 \%)$ who were married and 15 respondents $(30,6 \%)$ who were not married.

To know the influence of university cooperative information system toward service quality applies linier regression simple analysis in order to get independent variable coeeficient that can be measured by elasticity score. Independent variable is university cooperative information system and dependent variable is member quality service. Based on regression analysis by applying SPSS data processing programe, linear regression analysis result shows with equation as follows.

Service Quality $=5.100+0.300$ university cooperative information system

Normality Test with Chart Analysis

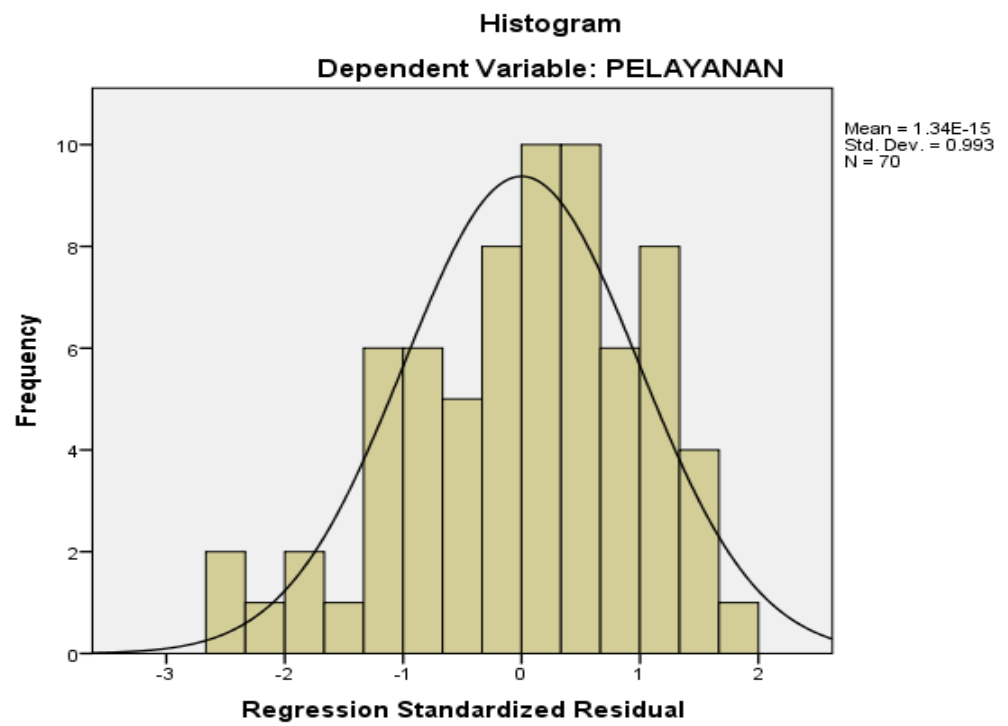

Based on histogram display is seen that dependent curve and regression standardized residual forms picture like a bell and based on normality test, regression analysis is deserved to apply. For normal distribution data can be seen in service variable dependent as follows.

Normal P-P Plot of Regression Standardized Residual

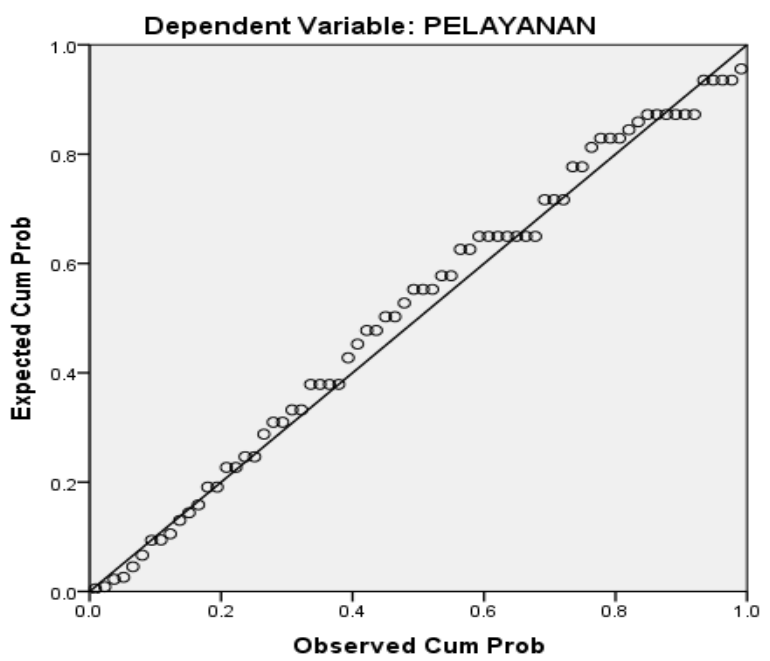


Based on normal P-Plot regression standardized display shows that dots spread diagonal line. Thereforee, based on normality test, regression analysis is deserved to apply.

Residuals Statistics ${ }^{\mathrm{a}}$

\begin{tabular}{|c|c|c|c|c|c|}
\hline & Minimum & Maximum & Mean & Std. Deviation & $\mathrm{N}$ \\
\hline Predicted Value & 92.6299 & 146.9724 & 138.2714 & 6.04477 & 70 \\
\hline Residual & -5.98452 & 4.72990 & .00000 & 2.07341 & 70 \\
\hline Std. Predicted Value & -7.551 & 1.439 & .000 & 1.000 & 70 \\
\hline Std. Residual & -2.844 & 2.248 & .000 & .985 & 70 \\
\hline
\end{tabular}

Heteroscedasticity Test



Based on output scatterplot analysis is seen that plot spreads randomly above zero number on the axis of regression standardized residual. Therefore, based on heteroscedasticity test applies graph analysis method on regression model that is formed, there is no heteroscedasticity symptom. Meanwhile $t$ test for significance test of independent variables $(X)$ in having an influence on dependent variable (Y) partially. With a degree of confidence 95 percent or significance 0,05 and degree of freedom as much as $69(N-k=70-1=69)$ dan $0.05 / 2=0.025$ by using two sides analysis is obtained score of $\mathrm{t}_{\text {table }}$ as much as 1,99495 and $-\mathrm{t}_{\text {-tabel }}$ as much as $-1,99495$. If $\mathrm{t}$-count is bigger than $\mathrm{t}$-table so that independent variable has significance influence partially toward dependent variable. Based on result, it is obtained the result that shows on table below as follows.

Result of Simple Linear Output Regression

\begin{tabular}{cccc}
\hline Variable & $\begin{array}{l}\text { Coefficient } \\
\text { Regression }\end{array}$ & $\mathrm{t}_{\text {count }}$ & $\mathrm{t}_{\text {table }}$ \\
\hline university cooperative information system & 0.300 & 10.020 & 1,99495 \\
\hline
\end{tabular}

Source: SPSS data processed

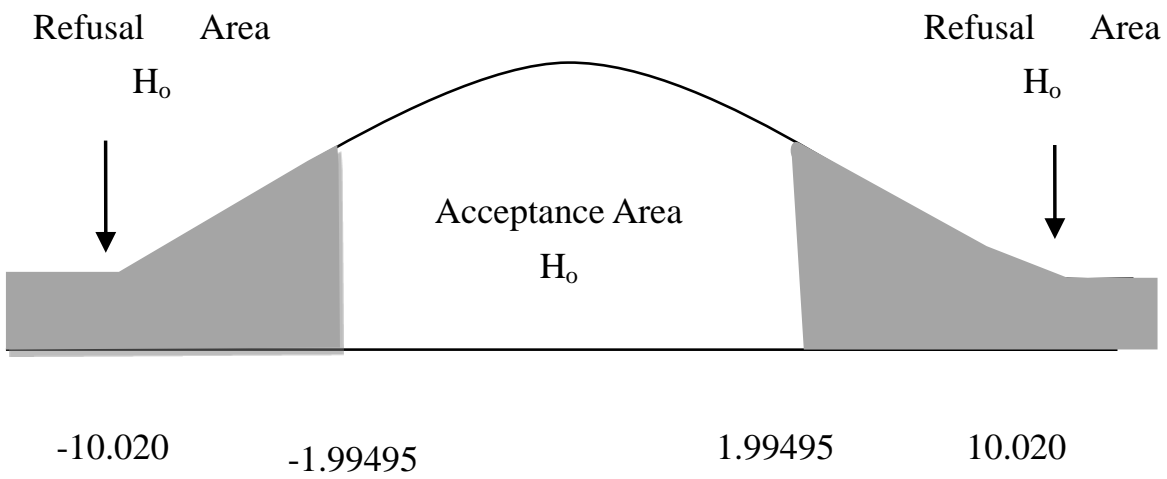

Based on classic assumption test and statistic test is able to know that applied model in this research deserves to apply to estimate independent variable toward dependent variable. 
The use of university cooperative information system, management enables to have time efficiency because each data that in put is automatically saved and it is not like in manual system, all data in put is done one by one and it takes time with high mistake level in data in put. The benefit from the use of this university cooperative information system, cooperative can provide a real data so that cooperative member can check and evaluate his/her own finance. Therefore, each cooperative member is able to consider and measure the total loan, which is expected and to check cash flow of finance data openly every time.

\section{Conclusion}

Based on research result, university cooperative information system based on website can answer variety desire that is expected from cooperative and it can be applied by management and member because it is simple, easy, and flexible. Management can access data easily, fast, and accurate and can check member finance development every time or period. It is because when data is processed automatically will influence to other note that refer to finance from each member. Service quality to cooperative member is able to be more maximal and member activity or management activity is not an obstacle to communicate because every member want can be complied by programe that has been provided so that management enables to know what member want.

\section{Acknowledgement}

The research is financed by DIKTI through Kopertis Regional Four West Java. Special thank is addressed to LPPM Universitas Muhammadiyah Sukabumi that has facilitated so that all research process can run well.

\section{References}

Akyuwen, R. (2016). Mengenal Lembaga Keuangan Mikro. Yogyakarta: Pustaka Pelajar.

Indrawan, R., \& R Poppy Y. (2012). Metodelogi Penelitian. Bandung: PT Refika Aditama.

Sedan, N., \& Veronica. (2015). Metodologi Penelitian Akuntansi dan Bisnis, Teori dan Praktek. Bandung: Ghalia Indonesia.

Simamora, H. (2012). Akuntansi Manajemen, Duri: Star Gate Publisher.

Siswanto, H. B. (2012). Pengantar Manajemen, Bandung: Remaja Rosdakarya.

Sitio, A., \& Halomoan T. (2001). Koperasi: Teori dan Praktek. Jakarta: Erlangga.

Sugiyono. (2016). Metode Penelitian Kuantitatif. Bandung: CV. Alfabeta.

Sumarni, M., \& Salamah W. (2005). Metodologi Penelitian Bisnis. Yogyakarta: Andi Offset.

Susanto, A. (2008). Sistem Informasi Akuntansi, Struktur Pengendalian Resiko Pengembangan. Bandung: Lingga Jaya.

Tambunan, T. TH. (2014). Perekonomian di Indonesia. Bogor: Ghalia Indonesia.

Triani, I N. A,. Merlyana D. Y,. \& Ricky E. P. (2017). Sistem Informasi Akuntansi. Jakarta: Salemba Empat.

\section{Copyrights}

Copyright for this article is retained by the author(s), with first publication rights granted to the journal.

This is an open-access article distributed under the terms and conditions of the Creative Commons Attribution license which permits unrestricted use, distribution, and reproduction in any medium, provided the original work is properly cited. 